\title{
Tuberculous Otitis Media with Facial Palsy in Pulmonary Tuberculosis Treated Patient
}

\author{
Abdur Rahman* and Sharma SC \\ Department of ENT, J N Medical College \& Hospital, Aligarh Muslim University, India
}

Submission: December 01, 2017; Published: January 05, 2018

*Corresponding author: Abdur Rahman, Senior Resident, Department of ENT, J N Medical College \& Hospital, Aligarh Muslim University, Aligarh, UP-202001, India, Tel: +919045449469; Email: abdurrahman6034@gmail.com

\begin{abstract}
Tuberculous otitis media is relatively rare and often masquerade as other common otological conditions resulting in delay of diagnosis and complications of disease. It is usually characterized by painless chronic ear discharge with multiple tympanic membrane perforation and presence of abundant granulation tissues in the middle ear on examination. We report the case of a 35 year old man who presented with symptoms of acute otitis media secondary to tuberculosis..
\end{abstract}

Keywords: Otitis media; Tuberculosis; Tympanic membrane

\section{Introduction}

Mycobacterium tuberculosis infection remains among the most insidious diseases worldwide [1]. Regarding extrapulmonary M. tuberculosis infection, $95 \%$ of cases involve the head-neck region (larynx, lymph nodes, tonsils, pharynx, oral cavity, salivary glands, and external and middle ears) [2].

Tuberculosis is a chronic granulomatous infection that can infect any part of the temporal bone [3]. Tuberculosis affects the middle ear through three routes; aspiration of mucus through the Eustachian tube, blood borne dissemination from other tuberculous foci or direct implantation through the external auditory canal and tympanic membrane perforation. Middle ear involvement in the absence of active pulmonary disease is rare, but may occur. Facial paralysis associated with chronic otitis media suggests a high probability of cholesteatoma, and surgical intervention is appropriate. The mechanism of facial paralysis associated with cholesteatoma may be compression or inflammation.

We present a case of TOM in a patient with associated facial palsy and healed pulmonary Koch's lesions. The diagnosis was made by clinical evaluation, radiography of the chest and histopathology.

\section{Case Report}

A 35 year male presented in our opd with complaints of left side purulent ear discharge for 3 months left sided facial muscles weakness for past one month and dizziness for 20 days and progressive diminution of hearing. It all started 5 years back when there was left otalgia which followed with purulent otorrhea which got relieved on taking medication. Patient complained of facial muscles weakness for 1 month. There was history of dizziness for last 20 days which relieved on medication.

Patient had completed antitubercular treatment under category 1 regimen 2 years back following which his pulmonary symptoms got relieved.

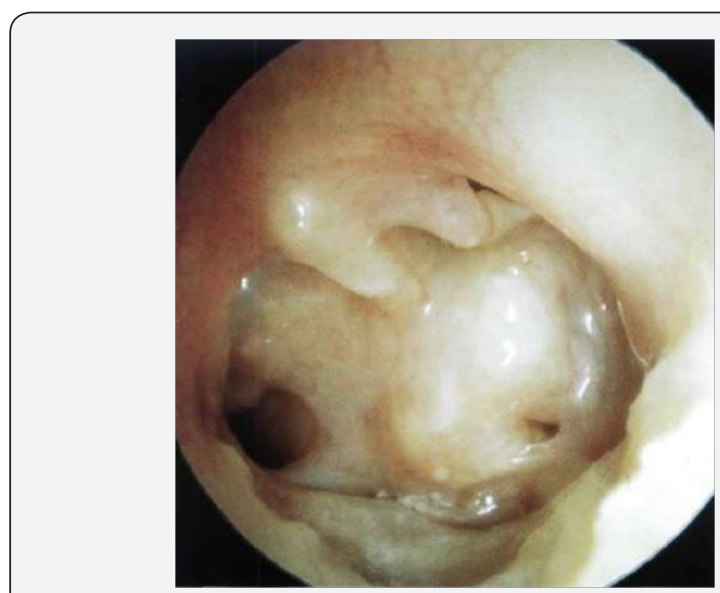

Figure 1 : Otoendoscopic view of middle ear.

Otoendoscopic examination of the left year revealed total perforation of tympanic membrane, characteristic pale middle ear mucosa, metalized handle of malleus adherent to promontory and hypotympanic air cells (Figure 1). The right 
tympanic membrane was essentially normal. There was no mastoid tenderness but Grade IV (House-Brackman score) facial palsy on left side (Figure 2).

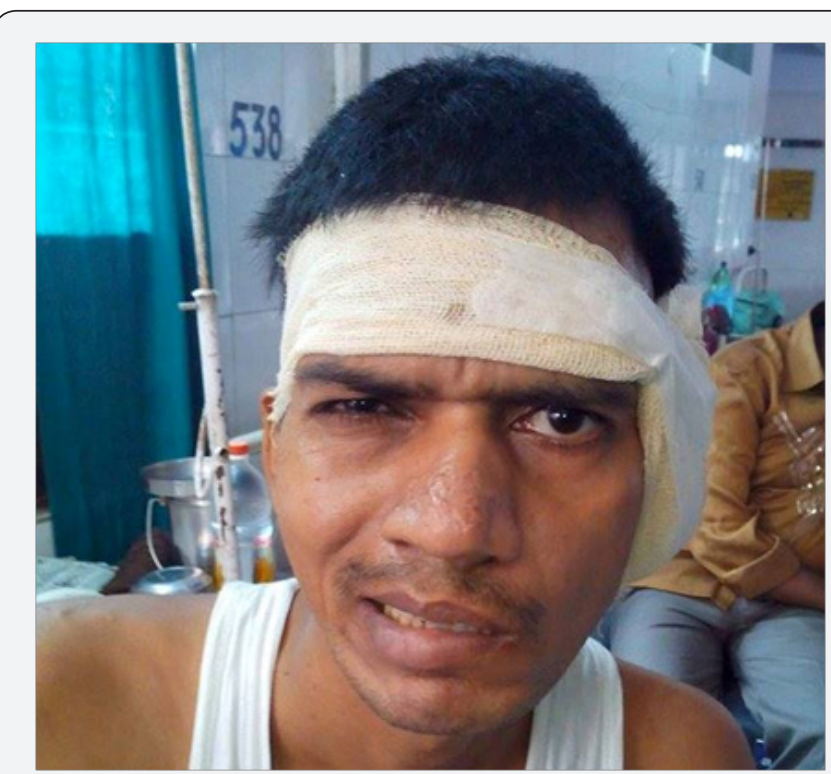

Figure 2: Grade 4 Facial nerve palsy (House Brackman Grading).

Audiometry shows severe to profound hearing loss in left ear and moderate to moderately severe hearing loss in right ear. A digital Chest X-ray revealed right sided healed tuberculous lesions with calcifications and fibrosis (Figure 3). Monteaux test was positive and Faraday stimulation showed $4.5 \mathrm{~mA}$ in right ear and $9.5 \mathrm{~mA}$ in left ear. CT scan temporal bone revealed metalized handle of malleus and exposed mastoid segment of the facial nerve (Figure 4). Modified radical mastoidectomy was done and pale granulations and fibrous tissues were seen, tegmen plate with a sheet of fibrous tissue dehiscent of some bone was found. The pale granulations were sent for histopathology examination.

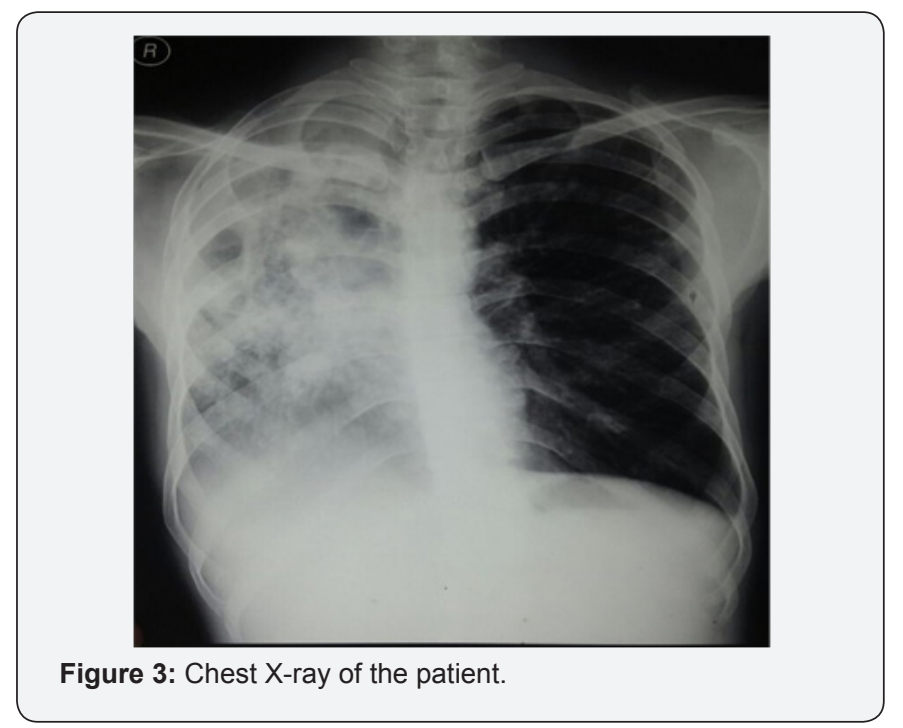

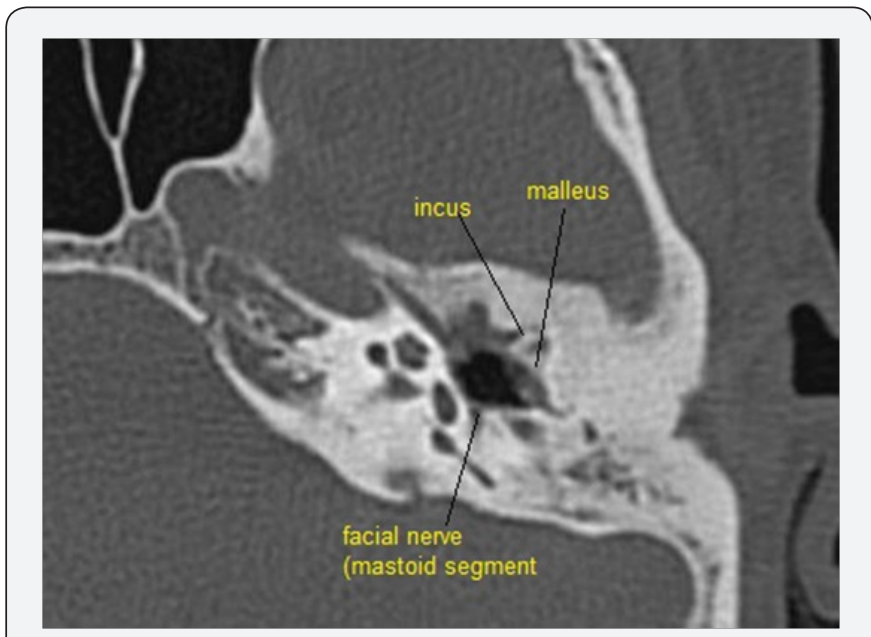

Firgure 4: CT Scan Temporal bone of patient Left (axial cut).

Histopathology report of granulations showed granulomas, composed of epitheloid cells, lymphocytes and occasional giant cells i.e., consistent with tuberculosis [4,5]. He was commenced on antitubercular medications under Category 2 as per Revised National Tuberculosis Control Program (RNTCP) and pulmonary symptoms got improved.

\section{Discussion}

The occurrence of tuberculosis of the middle ear has dramatically decreased, from about 1.3\%-18.6\% in the beginning of the last century, down to $0.04 \%$ of all cases of chronic suppurative otitis media according to a study report [3]. Wallmer [6] first described clinical features of tuberculous otitis in 1953, including painless otorrhea, multiple tympanic membrane perforations, granulation tissue in the tympanic cavity and mastoid, and bone necrosis with progressive conductive hearing loss and facial palsy. Varty et al. [7] further asserted that the combination of surgery and medical therapy improves prognosis.

All authors agree that treatment of TOM, including the nonlung-involving forms, has to include anti-TBC pharmacological protocols for at least six months [8]. With regard to the role of surgical treatment, it should be considered for the treatment of complications, such as subperiosteal abscesses, but it is controversial in case of uncomplicated TOM [8].

\section{References}

1. World Health Organization. Global tuberculosis control 2012. Geneva: WHO.

2. Bhalla RK, Jones TM, Rothburn MM, Swift AC (2001) Tuberculous otitis media-a diagnostic dilemma. Auris Nasus Larynx 28(3): 241-243.

3. Odetoyinbo O (1988) Early diagnosis of tuberculous otitis media. Journal of Laryngology and Otology 102(2): 133-135.

4. Cho YS, Lee HS, Kim SW, Chung KH, Lee DK, et al. (2006) Tuberculous otitis media: a clinical and radiologic analysis of 52 patients. Laryngoscope 116(6): 921-927. 
5. Vital V, Printza A, Zaraboukas T (2002) Tuberculous otitis media: a difficult diagnosis and report of four cases. Pathol Res Pract 198(1): 31-35.

6. Wallmer LJ (1953) Tuberculous otitis media. Laryngoscope 63(11): 1058-1077.

7. Varty S, Vaidya D, Parasram K, Prabhat D, Joshi S (2000) Tuberculous otitis media-are we missing it? Indian J Otolaryngol Head Neck Surg 52: 143-146.

This work is licensed under Creative Commons Attribution 4.0 Licens

DOI: $10.19080 / J H N S S .2018 .01 .555575$
8. Dunlap NE, Bass J, Fujiwara P, Hopewell P, Horsburgh CR, et al. (2000) Diagnostic standards and classification of tuberculosis in adults and children. American Journal of Respiratory and Critical Care Medicine 161(4): 1376-1395.

\section{Your next submission with Juniper Publishers will reach you the below assets}

- Quality Editorial service

- Swift Peer Review

- Reprints availability

- E-prints Service

- Manuscript Podcast for convenient understanding

- Global attainment for your research

- Manuscript accessibility in different formats

( Pdf, E-pub, Full Text, Audio)

- Unceasing customer service

Track the below URL for one-step submission https://juniperpublishers.com/online-submission.php 